\title{
Motivational Beliefs and Academic Achievement of University Students
}

\author{
Dr. Kulwinder Singh, Kavita \\ Reader Punjabi University, Patiala \\ Asstt. Prof. in Education SBBS Mem. Girls College of Edu. \#17044, Aggarwal Colony, Kanya Mandir Street, \\ Bathinda. Pin code-151005
}

\begin{abstract}
Teaching, learning and curricula are three important pillars of any education system. If anyone among them weakens, the whole education system will be prone to be collapsed. In order to enable students learn in effective manner, teachers are expected to make them aware to alternative ways of approaching learning situations. Through this research paper I would like to concentrate the motivational beliefs of learners and the impact of these beliefs on their achievement. I am sure that this paper will be beneficial for students, teacher educators and administrative bodies to understand the importance of motivation in learning and achievement.
\end{abstract}

\section{Introduction}

Quality of instruction in higher education is a matter of concern both to educational planners and practitioners. The underlying principle of teaching-learning process is purely psychological dealing with learning and motivation ( Pintrich and Shunk, 2002). Researchers have been developing new modes of assessment that take into consideration the relationship between motivational beliefs and academic achievement( Stiggins,2001; Segers, Duchy and Eduardo,2003)and achievement goal orientation vs academic outcome( Beghetto,2004).

The review of related studies is indicative of the fact that students' learning and performance depend upon their motivational beliefs and patterns of learning strategies. Still, the relationship of motivational beliefs with learning outcome is still inconclusive. Keeping in view the importance of motivational beliefs in academic achievement and also dearth of studies in this vital area of research in Punjab the researcher has to undertaken the research problem entitled as:-

\section{Motivational Beliefs And Academic Achievement of University Students Importance Of The Study}

Learning strategies and motivational beliefs have emerged as focal variables in teaching and learning process in last two decades. The importance of these concepts at different stages of education especially higher education has been highlighted in the number of studies ( Stiggins, 2001; Pintrich and Schunk, 2002). The empirical data base pertaining to motivational beliefs among university students vis-a vis academic achievement will be useful for educational administrators for defining of educational policy as per learners' needs. Hence the finding of study will provide an empirical database to gauge motivational beliefs and academic achievement of university students in order to improve the existing curriculum transaction in higher education.

\section{Objectives}

The objective of the study is to study motivational belief namely intrinsic goal orientation, extrinsic goal orientation, task value, control of learning beliefs, self efficacy for learning and performance and test anxiety in relation to high and low levels of academic achievement among university students.

\section{Delimitation Of Study}

The focus of the study was to explore the effect of motivational beliefs on academic achievement of university students. The study was delimited in the following manner:

The universe of the study has been limited to students of Punjabi University, Patiala.

\section{Operational Definition:}

1. Motivational beliefs are cognitive and meta cognitive variables in terms of intrinsic motivation ( the force which internally influence the learner to perform better), extrinsic motivation ( outsider rewards and punishment which effect academic achievement), self efficacy ( the belief that help the learner to organize and execute the action to produce given attainments), test anxiety ( a belief which measure the worry of the learner in taking the test), control of learning beliefs (students beliefs and efforts to learn), task value ( 
the importance of task or activity for learner) to be measured by motivational strategies for learning questionnaire ( Pintrich et. al. 1991).

2. Academic achievement refers to percentage marks obtained by university students at graduation level.

\section{Hypotheses}

There will be no significant difference in motivational belief namely intrinsic goal orientation, extrinsic goal orientation, task value, control of learning beliefs, self efficacy for learning and performance and test anxiety in relation to high and low levels of academic achievement among university students.

\section{Methodology}

The purpose of present study was to look into motivational beliefs among university students in relation to academic achievement of high and low achievers through descriptive method of research was followed.

\section{Universe Of Study And Sampling}

The universe of the study was students of Punjabi university campus, Patiala. A sample of 176 students was obtained in present study. The sampling distribution of students is shown in following table:

\section{Table}

Distribution of sample in terms of stream and gender

\begin{tabular}{|c|c|c|c|c|}
\hline Sr. No. & Streams & Male & Female & Total \\
\hline 1 & Arts & 20 & 43 & 63 \\
\hline 2 & Commerce & 15 & 33 & 48 \\
\hline 3 & Science & 26 & 39 & 65 \\
\hline & Total & 61 & 115 & $\mathbf{1 7 6}$ \\
\hline
\end{tabular}

\section{Research Tool: Motivational Strategies For Learning Questionnaire (MSLQ)}

\section{Collection Of Data}

The selected tool was administered personally by researcher, herself, to the selected students. The willingness on the part of the subject and truthful reporting were the criteria adapted to keep response of the subject for analysis.

\section{Tabulation And Treatment Of Data}

The high and low achiever groups were formed on the basis of achievement in graduation level.

The scores on motivational beliefs namely intrinsic goal orientation, extrinsic goal orientation , task value, control of learning beliefs, self efficacy for learning and performance and test anxiety respectively of motivational beliefs were computed using scoring key.the t-test was applied to find out differences in motivational beliefs of students in achievement groups separately for intrinsic goal orientation, extrinsic goal orientation, task value, control of learning beliefs, self efficacy for learning and performance and test anxiety.

\section{Analysis And Interpretation}

The means and SDs of high achievers, average achievers and low achievers on different beliefs, beliefs namely intrinsic goal orientation, extrinsic goal orientation, task value, control of learning beliefs, self efficacy for learning and performance and test anxiety in relation to their achievement is as follows:

\section{Table}

Means And Sds On Motivational Beliefs In Relation To Academic Achievement

\begin{tabular}{|c|c|c|c|c|c|c|}
\hline \multirow[t]{2}{*}{ Motivational Beliefs } & \multicolumn{2}{|c|}{$\begin{array}{c}\text { High achievers } \\
(\mathrm{N}=35)\end{array}$} & \multicolumn{2}{|c|}{$\begin{array}{c}\text { Average achievers } \\
(\mathbf{N}=\mathbf{1 0 8})\end{array}$} & \multicolumn{2}{|c|}{$\begin{array}{c}\text { Low achievers } \\
(\mathrm{N}=\mathbf{3 3})\end{array}$} \\
\hline & Mean & SD & Mean & SD & Mean & SD \\
\hline Intrinsic goal orientation & 5.78 & 0.96 & 5.47 & 1.19 & 5.68 & 1.19 \\
\hline Task value & 5.75 & 1.00 & 5.37 & 0.95 & 5.43 & 1.07 \\
\hline Control of learning beliefs & 5.52 & 1.27 & 4.96 & 1.21 & 5.43 & 1.28 \\
\hline
\end{tabular}


Table

The T-Values Testing Significance Of Mean Differences On Motivational Beliefs In Relation To Academic Achievement

\begin{tabular}{|l|c|c|c|}
\hline \multicolumn{1}{|c|}{ Motivational Beliefs } & $\begin{array}{c}\text { High Achievers Vs } \\
\text { Average Achievers }\end{array}$ & $\begin{array}{c}\text { High Achievers Vs Low } \\
\text { Achievers }\end{array}$ & $\begin{array}{c}\text { Average Achievers Vs } \\
\text { Low Achievers }\end{array}$ \\
\hline Intrinsic goal orientation & 1.55 & 0.46 & 0.88 \\
\hline Extrinsic goal orientation & 0.36 & 0.70 & 0.48 \\
\hline Task value & $2.00^{*}$ & 1.28 & $2.86^{* *}$ \\
\hline Control of learning beliefs & $2.33^{*}$ & 0.29 & 1.88 \\
\hline Self efficacy for learning and performance & 0.70 & 0.46 & 1.39 \\
\hline Test anxiety & 0.28 & 0.29 & 0.63 \\
\hline
\end{tabular}

$* \mathrm{p}<0.05, * * \mathrm{p}<0.01$

\section{Interpretation}

The above two tables shows the means, SD and t-values of university students in relation to their achievement. The t-values testing the significance of mean difference between high and average achievers groups on motivational beliefs namely, intrinsic goal orientation, extrinsic goal orientation, self efficacy for learning and performance and test anxiety is not significant at .05 level. The t-values on task value and control of learning beliefs are significant at .05 level.

The t-values testing the significance of mean difference between high and low achievers groups on motivational beliefs namely, intrinsic goal orientation, extrinsic goal orientation, task value, control of learning beliefs,self efficacy for learning and performance and test anxiety is not significant at .05 level.

The t-values testing the significance of mean difference between average and low achievers groups on motivational beliefs namely, intrinsic goal orientation, extrinsic goal orientation, control of learning beliefs, self efficacy for learning and performance and test anxiety is not significant at .05 level. The t-values testing the significance of mean difference between average and low achievers groups on motivational beliefs namely,task valve is significant at .01 level.

\section{Conclusions}

1. The high achievers and average achievers differ significantly in their motivational beliefs namely task value and control on learning beliefs. The mean performance of high achievers is more as compared to average achievers.

2. The students of high achievers and low achievers do not differ significant between them on motivational beliefs, namely intrinsic goal orientation, extrinsic goal orientation , task value, control of learning beliefs, self efficacy for learning and performance and test anxiety.

3. The students of average achiever and low achiever groups do not have significant difference on task value pattern of motivational belief. The mean performance of low achievers is more than high achievers.

\section{Educational implications:}

1. Students of higher studies have opportunity and responsibilities, for cultivating healthy motivational beliefs among themselves. By fostering beliefs grounded in positive goal orientations, they will increase the likelihood for their class and high achieving learning environment.

2. Since high achievers have been found to be better in task value and control on learning beliefs, it would be worthwhile to suggest that these motivational beliefs need to be made integral part of teaching learning process for academic excellence.

\section{Suggestion for further research}

1. Similar studies may be undertaken, in comparative prospective, on different levels such as higher secondary level and college level.

2. Similar studies may be conducted to find out the influence of teacher's motivating behavior on students learning and achievement.

3. Experimental studies may be conducted to find out level of improving the achievement level of low achievers by providing motivational strategies and learning packages.

\section{References}

[1]. Beghetto, R. A. ( 2004) towards a more complete picture of student learning: assessing students' motivational beliefs. Practical Assessment, Research And Evaluation,9(15)

[2]. Pintrich, P.R.,and Schunk, D. H.(2002). Motivation In Education: Theory, Research And Applications (2 ${ }^{\text {nd }}$ ed.)Columbus, OH; Merrill- Pentrich Hall

[3]. Segers, M., Duchy, F., Eduardo, C.(Eds.)(2003). Optimizing New Modes Of Assessment : In Research Of Qualities And Standards.Dordrecht: Kluwer.

[4]. Stiggins, R.J.(2001). Student- Involved Classroom Assessment ( $3^{\text {rd }}$ Ed.)Upper Saddle River, NJ: Prentice-Hall. 